УДК 637.12.05:636.2

(C) 2012

Шаповалов С. О., кандидат биологических наук

Институт животноводства НААН Украины (г. Харьков)

Аль-Бази Мезхер Камиль, аспирант *

Харьковская государственная зооветеринарная академия

\title{
БЕЛКОВОСТЬ И СЫРОПРИГОДНОСТЬ МОЛОКА КОРОВ РАЗНЫХ ПОРОД
}

\section{Рецензент - кандидат биологических наук Л. Н. Россо}

Викладені матеріали з вивчення білковості та сиропридатності молока, отриманого від корів трьох порід: симентальської, червоно-рябої та чорно-рябої. До завдань досліджень входило визначення фракційного (за масовою часткою казейну та його фракцій, альбуміну та глобулінів) і амінокислотного складу білків (співвідномення незамінних $і$ замінних амінокислот, їх скори, визначення лімітуючих амінокислот білка молока кожної з порід), швидкості згортання та якості згустку молока, одержаного під дією сичужного ферменту.

Ключевые слова: белок, аминокислотыл, скор, лимитирующие аминокислоты, фракции белка, сыропригодность, молоко, породы.

Постановка проблемы. Нормальная жизнедеятельность организма в значительной степени зависит от удовлетворения потребности в полноценном белке. Приоритетным источником таких белков являются белки животного происхождения, в том числе молока, имеющие практически стопроцентную усвояемость. В связи с тем, что синтез белка в значительной степени генетически детерминирован [3, 12, 14], представляет научный и практический интерес исследование породных особенностей производства молочного белка и его качественная характеристика как по составу, так и по технологическим свойствам.

Анализ последних публикаций по исследуемой проблеме показал ее актуальность $[2,3,4]$ как по влиянию породы на белковость молока $[11,12,14]$, так и поустановлению зависимости технологический свойств молока от его физикохимических характеристик и состава белков $[1$, $2,5,13]$. Несмотря на многочисленные исследования в данной области, полученные результаты не всегда сопоставимы, так как экспериментальные материалы получены в разных хозяйственно-климатических зонах. Проведение опытов в условиях однотипного содержания и кормления при действии паратипических факторов одинаковой силы и вектора направления позволяют объективно оценивать проявление генетического потенциала сравниваемых пород.

Целью данной работы было изучение белковости молока трех пород: симментальской, черно-пестрой и красно-пестрой, содержащихся в аналогичных хозяйственных условиях востока Украины.

Материал и методика. Для выполнения поставленной задачи в 2011-2012 гг. в племзаводе «Родина» Богодуховского района Харьковской области был проведен хозяйственный опыт на трех группах лактирующих коров (по 12 голов в каждой).

В первую группу входили коровы симментальской породы, во вторую - красно-пестрой, в третью - черно-пестрой. На начало опыта все животные были на 57-70-м дне лактации; исследование молочной продуктивности проводили до конца лактации. Все аналитические исследования проводили в соответствии со стандартными, общепринятыми методиками.

Химический состав молока оценивали посезонно на анализаторе Bentley 150 (США). Аминокислотный (АК) состав белков молока определяли на анализаторе AАA - 339 М (Чехия) в исследовательском центре института животноводства, аккредитированном согласно ДСТУ/ISO/IEC 17025:2006.

Скор незаменимых аминокислот (НЗАК) рассчитывали по формуле [3, 15]:

$$
\text { Скор }=\frac{\text { содержание аминокислоты (в мг) }}{\text { содержание этой же аминокислоты (в мг) }} * 100 \% \text {. }
$$

Для определения содержания АК в «идеальном» белке использовали шкалу адекватности, предложенную ФАО/ВОЗ (мг/г белка):

* Научный руководитель - доктор сельскохозяйственных наук В. Г. Прудников 
СІЛЬСЬКЕ ГОСПОДАРСТВО. ТВАРИННИЦТВО

\begin{tabular}{|c|c|}
\hline \hline $\begin{array}{c}\text { Название } \\
\text { амзаменимых }\end{array}$ & $\begin{array}{c}\text { Количество в мг незамени- } \\
\text { мых аминокислот в 1 г } \\
\text { «идеального» белка }\end{array}$ \\
\hline Валин & 50 \\
\hline Изолейцин & 40 \\
\hline Лейцин & 70 \\
\hline Лизин & 55 \\
\hline Метионин+цистин & 35 \\
\hline Треонин & 40 \\
\hline Триптофан & 10 \\
\hline Фенилаланин & 60 \\
\hline
\end{tabular}

Расчет общей ценности НЗАК (G) проводили в соответствии с требованиями для взрослого организма, рассчитывая их среднюю геометрическую величину по формуле:

$$
G=\sqrt[n]{\left(x_{1} \cdot x_{2} \cdot \ldots x_{n}\right)} .
$$

При оценке индивидуальных проб молока на анализаторе Bentley 150 (США) отбирали по 5 проб с каждой группы для анализа белковых фракций, который проводили методом электрофореза на бумаге [10]. Сыропригодность молока оценивали по скорости образования сгустка под действием сычужного фермента (по методу 3. Х. Диланяна [7]), а его качество - по сычужнобродильной пробе (ГОСТ 9225-84 4.4) [6].

Результаты исследований. В целом за лактацию от коров симментальской породы получено $5221 \pm 232$ кг, от красно-пестрой - 5389 314 кг, от черно-пестрой - $4541 \pm 285$ кг молока; при этом количество белка, произведенного за лактацию, соответственно, составило $159 \pm$ кг, $167 \pm$ кг, $136 \pm$ килограмма.

В таблице 1 представлены результаты анализа аминокислотного состава белка молока изучаемых пород.

Из представленных данных видно, что суммарное количество АК в анализируемых образцах молока, полученных от коров разных пород, было достаточно близким (32,0-32,3 г/кг), как и сумма незаменимых аминокислот (14,5-15 г/кг), от которых в значительной степени зависит биологическая полноценность белков молока. Доля НЗАК от общей суммы АК в белке молока коров симментальской и черно-пестрой пород составила $46,2 \%$ и $46,1 \%$ соответственно, у краснопестрой была несколько выше - 46,7\%.

\section{1. Аминокислотный состав белка молока коров разных пород}

\begin{tabular}{|c|c|c|c|}
\hline \multirow{2}{*}{ Наименования аминокислот } & \multicolumn{3}{|c|}{ Породы } \\
\hline & симментальская & красно-пестрая & черно-пестрая \\
\hline Содержание протеина, г/кг & 33,0 & 33,4 & 32,7 \\
\hline \multicolumn{4}{|c|}{ Незаменимые аминокислоты, (НЗАК, ЕАА), г } \\
\hline Лизин & 1,9 & 2,1 & 1,9 \\
\hline Метионин + цистеин & 1 & 0,9 & 1,1 \\
\hline Треонин & 1,3 & 1,6 & 1,2 \\
\hline Гистидин * & 0,7 & 0,5 & 0,6 \\
\hline Аргинин * & 1,3 & 1,2 & 1,3 \\
\hline Валин & 1,7 & 1,8 & 1,7 \\
\hline Лейцин & 3 & 3,2 & 3 \\
\hline Изолейцин & 1,3 & 1,3 & 1,4 \\
\hline Фенилаланин & 1,2 & 1,1 & 1,3 \\
\hline Тирозин & 1,4 & 1,3 & 1,4 \\
\hline Сумма НЗАК & 14,8 & 15,0 & 14,9 \\
\hline \multicolumn{4}{|c|}{ Заменимые аминокислоты (ЗАК, NEAA), г } \\
\hline Аспарагиновая & 1,7 & 2,0 & 1,8 \\
\hline Серин & 2,0 & 1,8 & 1,9 \\
\hline Глутаминовая & 8,0 & 7,8 & 8 \\
\hline Пролин & 3,8 & 3,8 & 3,9 \\
\hline Глицин & 0,7 & 0,5 & 0,7 \\
\hline Аланин & 1,0 & 1,2 & 1,1 \\
\hline Сумма ЗАК & 17,2 & 17,1 & 17,4 \\
\hline Сумма АК (ТАA) & 32,0 & 32,1 & 32,3 \\
\hline 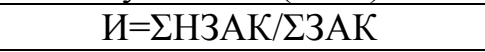 & 0,86 & 0,88 & 0,85 \\
\hline$U_{2}=\Sigma \mathrm{H} 3 \mathrm{AK} / \Sigma \mathrm{AK}$ & 0,462 & 0,467 & 0,461 \\
\hline
\end{tabular}

Примечание: * - НЗАК (для детского питания) 
Индекс незаменимых аминокислот (EAAI, без НЗАК для детского питания), рассчитанный как среднее геометрическое НЗАК, составляющих белки молока всех изучаемых пород, был близким, с некоторым преимуществом для белка молока красно-пестрой породы: у симменталов - 53,31, у красно-пестрой - 55,08, у черно-пестрых $-53,83$ единиц. Индекс, характеризующий соотношения НЗАК/ЗАК в белке молока красно-пестрой породы, также был сравнительно выше, чем в белке молока других сравниваемых пород.

В спектре выделенных НЗАК молочного белка максимальная доля принадлежала лейцину, среди ЗАК - глутаминовой кислоте и пролину. В минимальных количествах (меньше 1 г/кг) среди НЗАК был гистидин, ЗАК - глицин.

Для определения биологической ценности белка из ряда биологических и химических методов нами был выбран метод расчета аминокислотного скора, позволяющий определить лимитирующую аминокислоту. Скор рассчитывали по процентному соотношению каждой из НЗАК в белке молока по отношению к ее содержанию в «идеальном» белке.
Анализ полученного материала показал, что для белков молока всех изучаемых пород лимитирующим был серосодержащий метионин, содержание которого составило 80-97,1\% от его величины по шкале адекватности в «идеальном» белке (по ФАО/ВОЗ). В связи с важной функцией треонина в регуляции обмена, в частности, по его влиянию на выделение экзогенного азота из организма человека, ведущее к потери веса, ФАО предложили оценивать сбалансированность эссенциальных аминокислот белка также и по содержанию этой аминокислоты. В белке молока коров симментальской и красно-пестрой пород содержание треонина превышало его содержание в «идеальном» белке, а в белке коров черно-пестрой породы скор этой аминокислоты был на уровне 92,7 \% (по отношению к «идеальному» белку), что дает основание отнести ее так же к лимитирующим аминокислотам в белке молока коров этой породы.

В таблице 3 представлены данные, характеризующие соотношения белковых фракций молока изучаемых пород.

\section{2. Скор аминокислот белка молока по отночению к «идеальному» белку}

\begin{tabular}{|c|c|c|c|c|c|c|c|}
\hline \multirow{3}{*}{$\begin{array}{c}\text { Наименование } \\
\text { незаменимых } \\
\text { аминокислот, } \\
\text { НЗАК }\end{array}$} & \multirow{3}{*}{$\begin{array}{c}\text { Содержание } \\
\text { НЗАК в } \\
\text { «идеальном» } \\
\text { белке, мг/г }\end{array}$} & \multicolumn{6}{|c|}{ В молоке коров пород } \\
\hline & & \multicolumn{2}{|c|}{ симментальской } & \multicolumn{2}{|c|}{ красно-пестрой } & \multicolumn{2}{|c|}{ черно-пестрой } \\
\hline & & $\begin{array}{c}\text { содержа- } \\
\text { ние НЗАК, } \\
\text { мг/Г }\end{array}$ & $\begin{array}{c}\text { скор, } \\
\%\end{array}$ & $\begin{array}{c}\text { содержа- } \\
\text { ние НЗАК, } \\
\text { мг/Г }\end{array}$ & $\begin{array}{l}\text { скор, } \\
\text { \% }\end{array}$ & $\begin{array}{c}\text { содержа- } \\
\text { ние НЗАК, } \\
\text { мГ/Г }\end{array}$ & $\begin{array}{c}\text { скор, } \\
\%\end{array}$ \\
\hline Лизин & 55 & 59 & 107,3 & 65,4 & 118,9 & 58,8 & 117,6 \\
\hline $\begin{array}{c}\text { Метионин + } \\
\text { цистеин }\end{array}$ & 35 & 31,2 & 89,1 & 28,0 & 80,0 & 34,0 & 97,1 \\
\hline Треонин & 40 & 40,6 & 101,9 & 49,8 & 124,5 & 37,1 & 92,7 \\
\hline Гистидин & & 21,8 & & 15,5 & & 18,5 & \\
\hline Аргинин & & 40,6 & & 37,4 & & 40,2 & \\
\hline Валин & 50 & 53,1 & 106,2 & 56,1 & 112,2 & 52,6 & 105,2 \\
\hline Лейцин & 70 & 93,7 & 133,8 & 99,6 & 142,3 & 92,8 & 132,3 \\
\hline Изолейцин & 40 & 40,6 & 101,5 & 40,4 & 101,0 & 43,3 & 108,2 \\
\hline $\begin{array}{c}\text { Фенилаланин + } \\
\text { тирозин } \\
\end{array}$ & 60 & 81,0 & 133,3 & 74,7 & 124,5 & 83,5 & 137,0 \\
\hline
\end{tabular}

3. Фракционный состав белка молока исследуемых пород

\begin{tabular}{|c|c|c|c|}
\hline \multirow{2}{*}{ Показатели } & \multicolumn{3}{|c|}{ Молоко от коров породы } \\
\cline { 2 - 4 } & симментальская & красно-пестрая & черно-пестрая \\
\hline Содержание протеина (total) & $3,53 \pm 0,05$ & $3,59 \pm 0,05$ & $3,46 \pm 0,06$ \\
\hline Содержание белка (true) & $3,30 \pm 0,02$ & $3,34 \pm 0,02$ & $3,27 \pm 0,02$ \\
\hline в т. ч. казеина & $2,62 \pm 0,05$ & $2,72 \pm 0,04$ & $2,58 \pm 0,06$ \\
\hline$\alpha$ & $1,09 \pm 0,03$ & $1,21 \pm 0,04$ & $0,89 \pm 0,03$ \\
\hline$\beta$ & $1,14 \pm 0,03$ & $1,16 \pm 0,03$ & $1,29 \pm 0,03$ \\
\hline$\gamma$ & $0,39 \pm 0,04$ & $0,35 \pm 0,03$ & $0,40 \pm 0,04$ \\
\hline альбумина & $0,55 \pm 0,03$ & $0,45 \pm 0,03$ & $0,54 \pm 0,04$ \\
\hline глобулинов & $0,13 \pm 0,01$ & $0,17 \pm 0,02$ & $0,15 \pm 0,01$ \\
\hline \hline
\end{tabular}


Обращают на себя внимание близкие величины содержания «истинного» (true) белка в молоке изучаемых пород и тенденция к повышенному уровню казеина $81,4 \%$ в молоке краснопестрой породы (против 79,4-79,7 \% у симменталов и черно-пестрых коров, соответственно).

В сыроделии наиболее ценными являются $\alpha$ - и $\beta$-фракции казеина, переходящие под действием сычужного фермента в сырное зерно $[2,4,9]$. В белке изучаемых пород суммарная доля этих фракций составила: у симменталов - 84,9 \%, у красно-пестрых $-87,3 \%$, у черно-пестрых $-84,5 \%$ от общего содержания казеина, что свидетельствует о возможном более эффективном использовании молока красно-пестрой породы при изготовлении сыра.

Гамма-фракция казеина - как неосаждаемая сычужным ферментом - переходит в сыворотку и является составной частью потерь азотсодержащих веществ при производстве сычужных сыров. Самая высокая доля этой фракции казеина $(15,5 \%)$ отмечена у коров черно-пестрой, а самая низкая $(12,7 \%)$ - у красно-пестрой породы.

Общая доля сывороточных белков молока, теряемых при производстве сычужных сыров, самая низкая у коров красно-пестрой породы $18,6 \%$, несколько выше - у симментальской $(20,6 \%)$, и самая высокая $(21,7 \%)-$ у чернопестрой породы молочного скота.

Важными технологическими показателями сыропригодности молока являются скорость свертывания белков под действием сычужного фермента и характер образовавшегося сгустка $[1,4]$.

При $37{ }^{\circ} \mathrm{C}$ инкубации молока под действием сычужного фермента свертываемость наступала: в молоке коров симментальской породы через $(34,1 \pm 0,7)$, в молоке коров красно-пестрой породы - через $36,4 \pm 0,6$, в молоке коров чернопестрой породы - через $35,7 \pm 0,5$ минут. Согласно полученным данным, молоко коров всех исследуемых пород относится к желательному для сыроделия II типу.

При постановке сычужно-бродильной пробы, полученные после 12 часов инкубации молока $(\mathrm{t}=38,1 \pm 1)^{\circ} \mathrm{C}$ сгустки, согласно ГОСТ 9225 , были отнесены к I классу (с гладкой поверхностью,

\section{БИБЛИОГРАФИЯ}

1. Антила В. В. Сычужная активность молока / В. В. Антила, Э. Альсаари, Э. Луоманпере // Тезисы докладов ХХІ молочного конгресса. - М., 1982. - ЦНИИТЭПмясомолпром. - Т. 1. - Кн. 1. - С. 294.

2. Буткус К. Д. Оценка сыропригодности молока упругие на ощупь, без глазков на продольном срезе, сыворотка прозрачная, не тягучая, не горькая), или ко II классу (сгусток мягковатый, с единичными глазками (не более 10), с неровными краями, без вспучивания). Из 20 исследуемых образцов молока от коров каждой породы полученные сгустки были отнесены: в молоке коров симментальской породы 18 образцов $(90 \%)$ - к I и $2(10 \%)$ - ко II классу; в молоке коров красно-пестрой породы 17 (85\%) - к I и 3 $(15 \%)$ - ко II классу; в молоке коров чернопестрой породы $16(80 \%)$ - к I и $4(20 \%)$ - ко II классу.

Таким образом, исследуемые образцы по качеству сгустка имели преимущественно хорошую и удовлетворительную оценки. Образцов молока III класса по качеству сычужного сгустка обнаружено не было.

\section{Выводы:}

1. В аналогичных условиях содержания и кормления коровы красно-пестрой породы превосходили симментальскую и черно-пеструю породу как по удою, так и по величине продукции белка за лактационный период.

2. При относительно близкой сумме выделенных аминокислот из белка молока изучаемых пород обнаруживается более высокая биологическая полноценность белков молока коров красно-пестрой породы (по сумме НЗАК, индексу полноценности и соотношению НЗАК/ЗАК) в сравнении с симментальской и черно-пестрой породами.

3. Лимитирующей аминокислотой в белке изучаемых пород является серосодержащая аминокислота метионин, а в белке черно-пестрой породы кроме метионина еще и треонин.

4. Анализ фракционного состава белка показал, что, основываясь на содержание казеина и его $\alpha$ - и $\beta$-фракциях, молоко всех изучаемых пород может рационально использоваться в сыроделии, при более эффективном использовании молока красно-пестрой породы.

5. Молоко коров всех изучаемых пород по скорости свертывания отнесено ко II, желательному для сыроварения типу. По качеству сырного сгустка лучшим оказалось молоко симментальской породы.

по физико-химическим показателем // Научные труды ВАСХНИЛ / Улучшение качества молока и молочных продуктов. - М. : Колос, 1980. C. 222. 
3. Галат Б. Ф. Молоко: производство и переработка / Б. Ф. Галат, В. И. Гриенко, В. В. Змиев и др. // Х., 2006. - 352 c.

4. Гавриленко М. Білковість - важливий показник молочної продуктивності корів. Фактори, які впливають на вміст білка у молоці корів / Тваринництво України. - №11, 2000. - С. 14-16. 5. Горбатова К. К. Сыропригодность молока // Переработка молока. - №5, 2003. - М. : ООО «Деловые Медиа». - С. 4-5.

6. ГОСТ 9225-84, п. 4.4. Молоко и молочные продукты. Методы микробиологического анализа.

7. Диланян 3. Х. Основы сыроделия. - М. : Легкая и пищевая промышленность. $-1984 .-280$ с.

8. Жебровский Л. С., Гаджиев Г. М. Биологическая полноценность молока по содержанию в нём аминокислот в зависимости от сезона года // Молочная промышленность. - №6, 1969. C. $18-21$.

9. Жебровский Л. С. Об аминокислотном составе молока / Л. С. Жебровский, Г. М. Гаджиев. Вопросы питания. - №2, 1969.

10. Резниченко Л. П. До методики визначення білкових фракцій казеїну у сироватці молока корів / Методики досліджень у тваринництві. K., 1970. - C. 58-67.

11. Сажин С. И., Катмаков П. С. Белковый состав молока коров разных пород // Вестник Российской Академии сельскохозяйственных наук. - №2, 1993. - С. 54-55.

12. Маркова К. В. Состав и технологические свойства молока коров разных пород // К. В. Маркова, В. П. Храмцов, Т. И. Базенко // Улучшение качества молока и молочных продуктов : Сборник научных трудов. - М., 1980. - С. 164-171.

13. Хаертдинов Р. А. Содержание белковых фракций и влияние их уровня на технологические свойства молока / Р. Хаертдинов, М. Афанасьев, Э. Губайдуллин // Молочное и мясное скотоводство. - №5, 1997. - С. 16-20.

14. Хаертдинов Р. А. Влияние породности коровы на качество и сыродельчнские свойства молока / Р. Хаертдинов, М. Нургалиев, А. Гатоуллин // Молочное и мясное смкотоводство. - №7, 2004. - C. 23-24.

15. http://intellegens.ru/forum/showthread.php?t=1305 